\title{
TEACHING VOCABULARY USING FLASHCARD
}

\author{
Titin Supriatin', Venska Prajna Rizkilillah² \\ ${ }^{1}$ IKIP Siliwangi \\ ${ }^{2}$ IKIP Siliwangi \\ ${ }^{1}$ titinsupriatin1403@gmail.com, ${ }^{2}$ venska1827@gmail.com
}

\begin{abstract}
Vocabulary learning and teaching has been considered as one of the most important mechanisms of any educational program since early. Teachers have been using many techniques to help the learners to develop their knowledge of vocabularies in quality and quantity. There are many media in teaching vocabulary, one of them is by using flashcard. Flashcard is one of media which can help the teacher to teaching English easily. Flash cards in teaching vocabulary are very simple visual aids and the teacher can make the students more active during the teaching learning process. The study was conducted to find out the effect of flashcard on the vocabulary of the sixth graders of elementary school. This study employed a pre-experimental research design with one group pretest and posttest. An the research method used in this research is quantitative research with experimental research method. The subject consisted of 29 students of the sixth grader class of SDN Rengasdengklok Selatan 2 in the academic year of 2017/2018. Data collection techniques used in this study is a test. The procedures of collecting data are pretest, treatment and posttest. The data were analyzed using the SPSS 21.0. Based on the analysis, the mean score in pre-test was 66.21 improve to 79.55 in post-test. The result of t-test showed that significant 2-tailed was lower than $0.05(0.000<0.05)$. It can be said that $\mathrm{H}_{0}$ is rejected, it means that there is effect of flashcard to the vocabulary of the sixth graders in SDN Rengasdengklok Selatan 2.
\end{abstract}

Keywords: Vocabulary, Flashcard, Quantitative research

\section{INTRODUCTION}

In the elementary school curriculum, teaching English covers four skills namely, listening, speaking, reading and writing. The four skills are supported by the learning of language elements. They are structure, vocabulary, pronunciation, and spelling. To develop students' language skill in reading, listening, speaking and writing, the learners must have some degree of vocabulary.

Vocabulary learning and teaching has been considered as one of the most important mechanisms of any educational program since early on. According to (Nation, 2005) The positive effects of vocabulary teaching are that it can provide help when learners feel it is most needed. This is particularly true for vocabulary teaching that occurs in the context of messagefocused activities involving listening, speaking, reading and writing, and where the teaching deals with items that learners see as being very relevant for the activity. While according to (Coady, J., \& Huckin, 1997) vocabulary is central to language and of critical importance to the typical language learner. The explanation is confirmed (Hornby, 2004) stated that vocabulary is a total number of words in a language that is used by a person. It means vocabulary is all the words that people use in a language. By learning vocabulary, the students can add many new words that used in their daily activity both they know and unknown before. Teachers have been 
using many techniques to help the learners to develop their knowledge of vocabularies in quality and quantity. Words can be learnt verbally and visually; since verbally refers to the old-fashion way of learning vocabulary like reading and memorizing, most attention has been drawn on visual techniques like pictures, flashcard-based instruction, photographs, word pictures, and wordlists.

Considering the importance of vocabulary competence in learning English, the teacher should find the appropriate technique and strategy to teach vocabulary to young learners, so the classroom will be more alive and the learners more enthusiastic to study English.

There are many media in teaching vocabulary, one of them is by using flashcard. According to (Baleghizadeh, S., \& Ashoori, 2011) a flash card is a cardboard consisting of a word, a sentence, or a simple picture on it.

Flashcard that is used as a teaching learning aid at elementary level is chosen to increase the students' vocabulary. It will make the student interested in studying vocabulary because most of them like to play such as a card. According to (Cross, 1991) flashcard is a simple picture on a piece of card or paper, which is probably the most widely used visual aids in language teaching. It means that flashcard is one of media which can help the teacher to teaching English easily. Flash cards in teaching vocabulary are very simple visual aids and the teacher can make the students more active during the teaching learning process. Flashcards are some kinds of media that can be used by the teacher in the classroom. They can increase their span of attention and concentration to study new words in English. From the previous elaboration, the present researcher is interested in investigating "Teaching Vocabulary Using Flashcard".

\section{METHOD}

An the research method used in this research is experimental method with pre-experimental design. Based on (Sugiyono, 2008) because there are still external variables that contribute to the formation of dependent variables, then the results of the experiment which is the dependent variable is not only influenced by independent variables. this may occur due to the absence of a control variable, and the sample is not randomly selected.

In this research, the purpose of the study the researcher conducted pre-experimental design with one group pre-test and post-test. This study classified as pre-experimental study, according to (Donald, 2010) because they provide little or no control of extraneous variables. From the statement above, since there is no control variable so, in this study the researcher use one group or class and uses pre and post test. In this design only took one group as its subject and it involves administering a pretest measuring the dependent variable, applying the experimental treatment $X$ to the subjects, and administering a posttest.

(Donald, 2010) state the design of this reasearch can be seen at the table below:

Table 1

One Group Pretest-Posttest Design

\begin{tabular}{|c|c|c|}
\hline Pretest & Treatment & Posttest \\
\hline $\mathrm{Y}_{1}$ & $\mathrm{X}$ & $\mathrm{Y}_{2}$ \\
\hline
\end{tabular}

Population of this research is the sixth grade students of SDN Rengasdengklok Selatan 2 in the academic year of 2017/2018. That have 5 classes and each class is about 29-30 students. 
Table 2

List of Population

\begin{tabular}{|c|c|c|}
\hline No & Class & Number \\
\hline 1 & VI A & 29 \\
\hline 2 & VI B & 30 \\
\hline 3 & VI C & 30 \\
\hline 4 & VI D & 30 \\
\hline 5 & VI E & 29 \\
\hline \multicolumn{2}{|c|}{ Total } & 148 \\
\hline
\end{tabular}

In this research will be sampling of population by using purposive sampling technique. In this research, the writer takes class VI E as the smaple. Researchers choose this class as the object of his research because consideration from English teacher in SDN Rengasdengklok Selatan 2. This study uses an instrument used to measure students' vocabulary comprehension. All the instruments of this study to obtain quantitative information in research. The instruments used in this study are pretest, treatment and posttest.

In collecting the required data in this research, the researcher used test as instrument. Pretest was conducted on February 5th 2018 followed by 29 taker. Items used for pretest consisted of 25 items multiple choice. The test was about vocabulary comprehension which is appropriate with the indicators of vocabulary comprehension and posttest was done on Monday, March 19th 2018 that was followed by 29 taker. The writer used the same test which used in the pretest. Items used for posttest consisted of 25 items multiple choice.

To be able to answer the problem formulation in this research, then the data obtained in this research must be processed first. The data in question is quantitative data obtained from pretest, posttest. For all data processing using the help of Statistical Product and Service Solution (SPSS) 21.0 for Windows program.

\section{RESULTS AND DISCUSSION \\ Results}

The researcher presented the data on teaching vocabulary using flashcard. The researcher presented and analyzed the data which had been collected through two kinds of test, they are pre-test and post-test. It was conducted for twenty nine students.

As mentioned before, the researcher used test as the instrument in collecting data. It was given to class VI E students of SDN Rengasdengklok Selatan 2. The number of question given by researcher was 25 questions. It was consist of multiple choice test. There were 29 students as respondent or subject at the research. The data of the students' score before and after teaching vocabulary using flashcard can be seen in the following table.

Table 3

Data Score of Pretest and Posttest

\begin{tabular}{|c|c|c|c|c|}
\hline No & Subject & $\begin{array}{c}\text { Pretest } \\
\text { Score }\end{array}$ & $\begin{array}{c}\text { Posttest } \\
\text { Score }\end{array}$ & $\begin{array}{c}\text { Gain } \\
\text { Score }\end{array}$ \\
\hline 1 & Student 1 & 62 & 78 & 16 \\
\hline 2 & Student 2 & 66 & 76 & 10 \\
\hline 3 & Student 3 & 78 & 84 & 6 \\
\hline 4 & Student 4 & 70 & 80 & 10 \\
\hline 5 & Student 5 & 74 & 80 & 6 \\
\hline 6 & Student 6 & 82 & 90 & 8 \\
\hline 7 & Student 7 & 74 & 84 & 10 \\
\hline 8 & Student 8 & 70 & 82 & 12 \\
\hline
\end{tabular}




\begin{tabular}{|c|c|c|c|c|}
\hline 9 & Student 9 & 82 & 96 & 14 \\
\hline 10 & Student 10 & 62 & 76 & 14 \\
\hline 11 & Student 11 & 74 & 80 & 6 \\
\hline 12 & Student 12 & 70 & 80 & 10 \\
\hline 13 & Student 13 & 74 & 84 & 10 \\
\hline 14 & Student 14 & 44 & 66 & 22 \\
\hline 15 & Student 15 & 48 & 60 & 12 \\
\hline 16 & Student 16 & 64 & 76 & 12 \\
\hline 17 & Student 17 & 64 & 84 & 20 \\
\hline 18 & Student 18 & 58 & 76 & 18 \\
\hline 19 & Student 19 & 72 & 98 & 26 \\
\hline 20 & Student 20 & 62 & 82 & 20 \\
\hline 21 & Student 21 & 46 & 66 & 20 \\
\hline 22 & Student 22 & 50 & 60 & 10 \\
\hline 23 & Student 23 & 66 & 76 & 10 \\
\hline 24 & Student 24 & 88 & 100 & 12 \\
\hline 25 & Student 25 & 68 & 76 & 8 \\
\hline 26 & Student 26 & 60 & 74 & 14 \\
\hline 27 & Student 27 & 64 & 88 & 24 \\
\hline 28 & Student 28 & 56 & 72 & 16 \\
\hline 29 & Student 29 & 72 & 84 & 12 \\
\hline \multicolumn{2}{|c|}{ Total } & $\mathbf{1 9 2 0}$ & $\mathbf{2 3 0 8}$ & $\mathbf{3 8 8}$ \\
\hline Score Minimum & $\mathbf{4 4}$ & $\mathbf{6 0}$ & $\mathbf{6}$ \\
\hline Score Maximum & $\mathbf{8 8}$ & $\mathbf{1 0 0}$ & $\mathbf{2 4}$ \\
\hline \multicolumn{2}{|r|}{ Mean } & $\mathbf{6 6 , 2 1}$ & $\mathbf{7 9 , 5 5}$ & $\mathbf{1 3 , 3 8}$ \\
\hline
\end{tabular}

Based on the data in Table 1, it can be seen that the average pretest score in class VI E is 66.21 and the standard deviation of pretest score is 10.762. while the average postest score in class VI E is 79,55. Based on the data it is seen that the average posttest score of class VIE is greater than the average pretest score. So, it can be concluded that the flashcard is helpful the students to increase their achievement in teaching vocabulary.

\section{The Result Normality Test}

Normality testing is conducted to determine whether the gotten data is normally distribution or not, because the sample is less than 30 then the normality test against the pretest and posttest score is done by Shapiro-Wilk test using SPSS 21.0 program with significance level of 0.05 . The result can be seen below:

Table 4

Test of Normality

\begin{tabular}{|l|r|r|r|r|r|r|}
\hline & \multicolumn{3}{|c|}{ Kolmogorov-Smirnov $^{\mathrm{a}}$} & \multicolumn{3}{|c|}{ Shapiro-Wilk } \\
\cline { 2 - 7 } & Statistic & \multicolumn{1}{c|}{ df } & \multicolumn{1}{c|}{ Sig. } & Statistic & \multicolumn{1}{c|}{ df } & \multicolumn{1}{c|}{ Sig. } \\
\hline PRETEST &, 107 & 29 &, $200^{*}$ &, 973 & 29 &, 649 \\
POSTEST &, 151 & 29 &, 088 &, 955 & 29 &, 241 \\
\hline
\end{tabular}

Based on the table above is known that the significance value from pre-test is 0.649 and from the post test is 0.241 . Both value from pre-test and post-test are bigger than 0.05 . The sig/p 
value on pre-test is 0.649 and it is bigger than $0.05(0.649>0.05)$ means that the data is in normally distribution. Then, for post-test score the value of sig/p is 0.241 and that is bigger than $0.05(0.241>0.05)$ means that the data is in normal distribution. It also means that $\mathrm{H}_{0}$ is accepted and $\mathrm{H}_{\mathrm{a}}$ is rejected. So, it can be interpreted that both of data (pretest and posttest score) are in normally distribution.

\section{The Result Homogeneity Test}

Homogeneity testing is conducted to know whether the gotten data has a homogeneous variance or not. To know the homogeneity, the researcher used Test of Homogeneity of Variances with SPSS 21.0 by the value of significance $(\alpha)=0.050$. The result can be seen below:

\section{Table 5}

Test of Homogeneity of Variances

Pretest and Posttest

\begin{tabular}{|c|c|c|c|}
\hline $\begin{array}{c}\text { Levene } \\
\text { Statistic }\end{array}$ & df1 & df2 & Sig. \\
\hline, 518 & 1 & 56 &, 475 \\
\hline
\end{tabular}

Based on the table above is known that the sig or p-value is 0.475 higher than 0.05 means $\mathrm{H}_{0}$ is accepted and $\mathrm{Ha}$ is rejected. So, it can be interpreted that the data is homogeny.

\section{Paired Sample T-test (t-test)}

Both data (pretest and posttest score) are normally distribution and have homogeneous variance, then do different test of two paired samples through SPSS 21.0 program using Paired Sample T-Test with significance level 0,05 .

For interpretation of decision based on the result of probability achievement, that is:

If the sig $>0.05$, means $\mathrm{H}_{0}$ is accepted

If the $\operatorname{sig}<0.05$, means $\mathrm{H}_{0}$ is rejected

Table 6

Paired Sample Test

\begin{tabular}{|c|c|c|c|c|c|c|c|c|c|}
\hline & \multicolumn{5}{|c|}{ Paired Differences } & \multirow{3}{*}{$\mathrm{t}$} & \multirow{3}{*}{ df } & \multirow{3}{*}{$\begin{array}{l}\text { Sig. } \\
(2- \\
\text { tailed })\end{array}$} \\
\hline & & \multirow[t]{2}{*}{ Mean } & \multirow[t]{2}{*}{$\begin{array}{l}\text { Std. } \\
\text { Deviatio } \\
\mathrm{n}\end{array}$} & \multirow[t]{2}{*}{$\begin{array}{l}\text { Std. } \\
\text { Error } \\
\text { Mean }\end{array}$} & \multicolumn{2}{|c|}{$\begin{array}{l}95 \% \text { Confidence } \\
\text { Interval of the } \\
\text { Difference }\end{array}$} & & & \\
\hline & & & & & Lower & Upper & & & \\
\hline Pair 1 & $\begin{array}{c}\text { PRETES } \\
\mathrm{T} \\
\text { POSTES } \\
\mathrm{T}\end{array}$ & $\begin{array}{c}- \\
13,345\end{array}$ & 5,374 & ,998 & $\begin{array}{c}- \\
15,389\end{array}$ & $-11,301$ & $-13,373$ & 28 & ,000 \\
\hline
\end{tabular}

Based on the table 4.5, output paired samples test shows the result of compare analysis with using $\mathrm{T}$ test. Output shows mean pre-test and post-test is -13.345 , standard deviation is 5.374, mean standard error is 0.998 . The lower different is -15.387 and upper different is -11.301 . The result test $\mathrm{t}=-13.373$ with $\mathrm{df}=28$ and significance is 0.000 .

Because significance 0.000 lower than $0.05(0.000<0.05)$ means that $\mathrm{H}_{0}$ is rejected and $\mathrm{H}_{\mathrm{a}}$ is accepted. Therefore, it concluded that there is the significant differences between pretest and posttest score where mean of posttest is 79.55 higher than mean of pretest is 66.21 means that there is any effect flashcard in teaching vocabulary to the student of the sixth graders in SDN Rengasdengklok Selatan 2. 


\section{Discussion}

From the research finding in chapter IV, descriptive statistical data of score pretest and posttest shows mean of pre-test is 66.21 and posttest is 79.55 has increased, So, it can be concluded that the flashcard is helpful the students to increase their achievement in learning vocabulary. Further data analysis continued by using statistical parametric test, namely Paired Samples TTest with 5\% significance level. Obtained Sig. (2-tailed) is 0,000. Because significance 0.000 lower than $0.05(0.000<0.05)$ means that $\mathrm{H}_{0}$ is rejected and $\mathrm{H}_{\mathrm{a}}$ is accepted. Therefore, from both mean it can concluded that there is significant differences in the students' achievement of vocabulary comprehension means that teaching vocabulary comprehension using flashcard is effective. Means that there is any effect flashcard in teaching vocabulary to the student of the sixth graders in SDN Rengasdengklok Selatan 2.

Based on the result of research findings and explanation above, it can be concluded that using flashcard is effective in teaching vocabulary comprehension at elementary school especially for the sixth grade students of SDN RengasdengklokSealatan 2. It proved that flashcard has significant effect to the students' vocabulary comprehension achievement.

\section{CONCLUSIONS}

The research reveals that the students' difficulties in vocabulary comprehension can be effectively improved by using flashcard. It can be shows from the result of pretest and posttest as follow:

The students get difficulties in vocabulary comprehension. It can be seen, the students achievement before being taught by using flashcard their achievement in vocabulary comprehension is fair because the mean of the total score of 29 students is 66.21. After, the researcher applied vocabulary learning using flashcard to the students with the students' condition that mentioned above it shows increasing in their vocabulary comprehension achievement where their achievement is very good because the mean of the total score of 29 students is 79.55 . So, it can be concluded that the flashcard is helpful the students to increase their achievement in learning vocabulary.

The statistical using paired sample T-test with the significant level 0.05, Obtained Sig. (2-tailed) is 0,000 . Because significance 0.000 lower than $0.05(0.000<0.05)$ means that $\mathrm{H} 0$ is rejected and $\mathrm{Ha}$ is accepted. So, from both mean it can concluded that there is significant differences in the students' achievement of reading comprehension means that teaching vocabulary comprehension using flashcard is effective. Therefore, the students' vocabulary comprehension achievement is getting better that after being taught by using flashcard. In other words, there is effect of flashcard to the vocabulary of the sixth graders in SDN Selatan Rengasdengklok 2.

\section{AKNOWLEDGEMENT}

Firstly, The writer wants to deliver his great thanks to Allah SWT for His bless and kindness. It's His endless and continuous kindness that make him possible to complete the research paper with the title Teaching Vocabulary Using Flashcard in order to fulfill the requirement of S-1 degree in English Education Study Program, Language and Art Department of IKIP Siliwangi Bandung.

The writer also want to express his sincere thank to all of individual who has given the contribution for the writer. The writer want to extends his thank to:

1. Dr. Irma Savitri Sadikin, M.Pd., as the Head of English Education Study Program and as the first advisor who with her patience always gives her ideas, time, and, useful suggestions for me; 
2. Trisnendri Syahrizal, S.Pd.,M.Hum., as the second advisor who gives his correction and advices, so the writer can finish this script well;

3. All lecturers of English Education study program, for their knowledge, guidance, motivation and patient during his study at STKIP Siliwangi Bandung;

4. Mrs. Tety Widayati, S.Pd., the headmaster of SDN Rengasdengklok Selatan 2 for his kindness to gives him enoughtime to conduct a research;

5. Mr. Tedi Rosdiana, S.Pd., as the English teacher who would like to give him some supports and time in order to held his research;

6. The students of VI E who would like to give their cooperation;

7. The writer hands over much thank to my parents, and my husband who always their incessant support, pray, and love;

8. The big family of besties;

9. All of friends in English Education Study Program 2014, who cannot be mentioned one by one. Thank you for the suppport and all help given to the writer, you all the best.

Finally, this research paper is presented to English Education Study Program Language and Art Department of IKIP Siliwangi Bandung. The writer hopes this research paper can help the reader.

\section{REFERENCES}

Baleghizadeh, S., \& Ashoori, A. (2011). The Impact of Two Instructional Techniques on EFLLearners' Vocabulary Knowledge: Flash Card-based instruction versus Word Lists. MEXTESOL Journal, 35(2), 1-9.

Coady, J., \& Huckin, T. (1997). Second Language Vocabulary Acquisition. Cambridge University Press.

Cross, D. (1991). A Practical Handbook of Language Teaching.

Donald, A. (2010). Introduction to Research in Education Eight. United State : Wadsworth.

Hornby, A. (2004). Oxford Advanced Learners Dictionary of Current English. Oxford University Press.

Nation, P. (2005). Teaching Vocabulary. Asean EFL Journals.

Sugiyono. (2008). Metode Penelitian Kunatitatif Kualitatif dan R\&D. Bandung Alfabeta. 